\title{
Prevalence of Malocclusion among Indian Children Aged 12-15 Years Using Dental Aesthetic Index- A Systematic Review.
}

\author{
Prijitha Alex ${ }^{1}$, Shabana Achapatira Ganesh ${ }^{2}$, Fawaz Pullishery ${ }^{3}$, Rijitha Alex ${ }^{4}$ \\ ${ }^{I}$ Senior Lecturer, Department of Public Health Dentistry, Educare Institute Of \\ Dental Sciences, Malappuram, Kerala. \\ ${ }^{2}$ Reader, Department of Public Health Dentistry, The Oxford Dental College \&Amp; \\ Hospital, Bengaluru. \\ ${ }^{3}$ Senior Lecturer, Department of Public Health Dentistry, Educare Institute Of \\ Dental Sciences, Malappuram, Kerala \\ ${ }^{4}$ Senior Lecturer, Department of Oral Pathology, Anoor Dental College, \\ Muvattupuzha, Kerala \\ Correspondence : Fawaz.Pullishery, email: drfawazp@gmail.com
}

\begin{abstract}
Introduction: Malocclusion has a large impact on both individuals and society in terms of discomfort, quality of life, social and functional limitations.

Aim: To systematically review the literature on prevalence of malocclusion among 12-15 year old Indian children using Dental Aesthetic Index.

Methods: A literature search was obtained for relevant articles on malocclusion status of Indian children aged 12-15 years using 4 electronic retrieval systems and data bases. The search was limited to human studies, articles published during the period of January 2000 to July 2014 and those measured malocclusion using Dental Aesthetic Index. The methodological quality of an article was assessed based on Cochrane Collaboration criteria.Final inclusion was determined by evaluating the article based on relevance criteria.

Results: A total of 856 articles were identified by the literature search, out of which 17 articles were selected for the final review. These articles were read in full and scored independently by two reviewers and evidence was extracted for all the outcomes measured. Prevalence of malocclusion among Indian children ranged from $20 \%$ to $40 \%$ and Maxillary overjet was the most common type of malocclusion which accounted for $38 \%$ to 78\%. Conclusion: Malocclusion among Indian children is on a rise. It is not a single entity but rather a collection of situations, each in itself constituting a problem, and can be complicated by a multitude of genetic and environmental causes. The need to implement preventive and interceptive orthodontic care is of utmost importance.
\end{abstract}

Keywords:Dental Aesthetic Index, Prevalence, Malocclusion

\section{Introduction}

The face can be described as the window to the mind and body, as it is a region that is important in both communication and emotional display. Physical appearance, including the dentition, is an important aspect of human activity, as one aims to be adored, respected or accepted by those around him/her and may be the single feature that has the greatest impact on behavioural patterns and personal interactions. Malocclusion has been described as an Handicapping Dentofacial Anomaly which causes defacement or which hinders function and necessitating treatment "if the mutilation poses an obstacle to the patient's physical or emotional wellbeing"'(WHO,1987). ${ }^{1}$

Malocclusion has a huge burden on individual and society in terms of discomfort and Quality of Life. In recent years, lot of efforts have been put forward on measuring the severity and prevalence of malocclusion and orthodontic treatment need worldwide. To assess the resources required to meet the orthodontic treatment demand and rationally plan for their provision requires population- level data. Gray and Demirjan (1977) ${ }^{3}$ claimed that the most reliable assessments of malocclusion are made in permanent dentition so avoiding the problems of assessment associated with dental development. ${ }^{2}$

It is outward that the number of children seeking orthodontic treatment has intensely amplified over the past few decades. Prevalence of malocclusion exists in a large proportion in varying regions of our country where ethnicity, nutritional status, religious beliefs and dietary habits play a pivotal role. The main advantage of orthodontic treatment to the patient is in enhanced dental aesthetics and psychSological well-being. Dental Aesthetic Index specifically measures dental aesthetics. By considering societal defined norms for dental 
appearance, it was claimed to recognize conditions that are hypothetically psychosocially handicapping. DAI is a cross cultural index absorbed on socially distinct dental aesthetics intended for use in permanent dentition.

A systematic review is an essential tool for summarizing evidence accurately and reliably. It gives a comprehensive search for all relevant studies on a specific topic and those identified are then appraised and synthesized according to predetermined and explicit criteria.Thus this systematic review aids to gather extensive documentation on age related prevalence and severity of malocclusion in India reported from 2000 to 2014 . So the current study aims to systematically assess the literature to find out the prevalence of malocclusion in 12-15 year old Indian children using Dental Aesthetic Index (DAI).

\section{Data sources and search strategy}

\section{Methodology}

A comprehensive literature search was executed from February 2014 using electronic retrieval systems and databases. PubMed (MEDLINE), Web of Science, EMBASE and Elsevier were utilized for this. The search was limited to human studies in English and articles published during January 2000 to July 2014. This period was chosen because malocclusion became the topic of interest in dentistry during this period and a lot of research was undertaken to report the etiology, the prevalence and treatment prospects of malocclusion in India.

The search was focused on using the keywords (Medical Subject Headings in MEDLINE) "Dental Aesthetic Index (DAI)", "Orthodontic treatment priority", "Orthodontic treatment needs", "Crowding", "Spacing", "Midline diastema", "Largest anterior maxillary irregularity", "Largest anterior mandibular irregularity", "Overjet”, “Anterior mandibular Irregularity”, "Overjet”, "Vertical openbite", "Molar relation", isolated or in different combinations using different Boolean operators. Reports in the grey literature, such as thesis, dissertations, product reports and unpublished studies, were not pursued. Special attention was paid to the article reference lists and related articles. This exercise was carried out independently by two authors (PA and AGS).

\section{Selection criteria and methodological quality assessment}

Titles and abstracts of articles obtained from the search strategy were screened. Only articles with regard to malocclusion among Indian children aged 12-15 years were eligible. Inclusion criterion was crosssectional studies reporting the prevalence of malocclusion and their exposure variables measured using Dental Aesthetic Index. Since WHO Oral Health Assessment Form (1997) also measures malocclusion using Dental Aesthetic Index, even those studies were included. Studies on children with different ethnic variations and otherwise abled were excluded from the search. Subsequently, potential relevant articles were read in full by the two authors (PA and AGS) and independently assessed for their methodological quality.

The methodological quality of an article was assessed using the criteria published by the Cochrane Collaboration, Dutch Branch (www.dcc.cochrane.org) ${ }^{28}$.

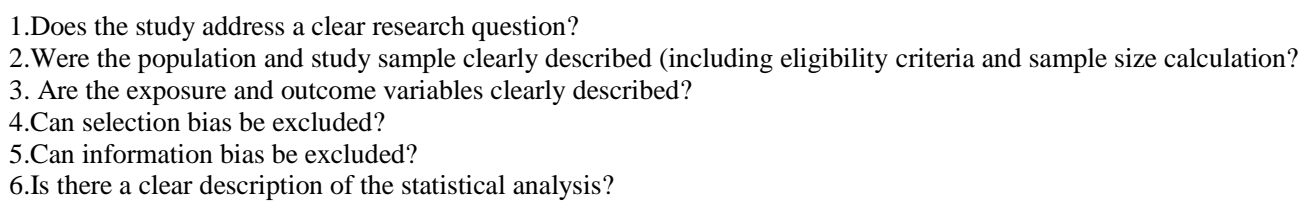

The exposure variables measured were

1. Missing incisor, canine and premolar teeth

2. Crowding in the incisal segments

3. Spacing in the incisal segments

4. Diastema

5. Largest anterior maxillary irregularity

6. Largest anterior mandibular irregularity

7. Anterior maxillary overjet

8. Anterior mandibular overjet

9. Vertical anterior openbite

10. Antero-posterior molar relation

The outcome variables measured based on DAI scores were: 
(A) Severity of malocclusion - No malocclusion, Definite malocclusion, Severe malocclusion Very severe malocclusion

(B) Treatment indication- No treatment, Elective, Highly desirable Mandatory treatment

For articles meeting all methodology quality criteria, relevance criteria ${ }^{28}$ were used to determine how much scientific weight could be assigned to the study findings. Grades of the scientific evidence were as follows: 'sufficient', 'fair' and 'insufficient'. Relevance criteria for evidence grade 'sufficient' assigned when ten exposure variables, treatment indication and prevalence of malocclusion were given. For evidence grade 'fair', treatment indication and prevalence of malocclusion was assessed but exposure variables were not measured. Where just the prevalence of malocclusion was given, evidence grade 'insufficient' was assigned. In case of disagreement between the two authors (PA and AGS) and inconsistency concerning assessing the methodological quality or the determination of the scientific weight to be assigned to the study findings, the opinion of author DBC was decisive.

\section{Data extraction}

Two authors (PA and AGS) extracted data independently, including information on malocclusion, study design, intervention, measurement instruments, study length and outcome.

\section{Results}

Summary of the included articles is provided in Table I. Prevalence of malocclusion is considered to be on increase with evolution and civilization. The detailed reviewing revealed that prevalence of malocclusion among Indian children ranged from $11.4 \%$ to $73.7 \%$. Among the exposure variables assessed, Crowding and maxillary overjet were found to be on the toplist (Table II).

TABLE I: Summary of the included articles

\section{SUMMARY OF INCLUDED ARTICLES}

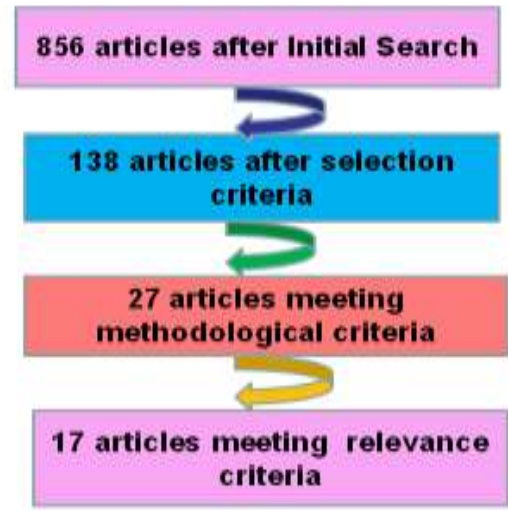

Table II

\begin{tabular}{|l|l|l|l|l|l|}
\hline Study & $\begin{array}{l}\text { No: of } \\
\text { subjects }\end{array}$ & $\begin{array}{l}\text { Exposure } \\
\text { variables }\end{array}$ & $\begin{array}{l}\text { Outcome } \\
\text { variables }\end{array}$ & Findings & $\begin{array}{l}\text { Relevance } \\
\text { criteria }\end{array}$ \\
\hline $\begin{array}{l}\text { 1. National } \\
\text { Oral health } \\
\text { survey } \\
(2002)\end{array}$ & 38559 & Assessed & Mentioned & $\begin{array}{l}\text { Prevalence among } \\
12 \text { years= 23.6\% } \\
15 \text { years }=23.9 \%\end{array}$ & Sufficient \\
\hline $\begin{array}{l}\text { 2. Suresh } \\
\text { Babu et al } \\
\text { (2005) }\end{array}$ & 300 & Assessed & Mentioned & $\begin{array}{l}\text { Overall prevalence } \\
=38.7 \%\end{array}$ & Sufficient \\
\hline $\begin{array}{l}\text { 3.Shiva } \\
\text { Kumar et al } \\
\text { (2009) }\end{array}$ & 1000 & Assessed & Mentioned & $\begin{array}{l}\text { Overall prevalence } \\
=19.9 \%\end{array}$ & Sufficient \\
\hline $\begin{array}{l}\text { 4. Pankaj S } \\
\text { et al (2010) }\end{array}$ & 1600 & Assessed & Mentioned & $\begin{array}{l}\text { Overall prevalence } \\
=11.4 \%\end{array}$ & Sufficient \\
\hline $\begin{array}{l}\text { 5. Shiva } \\
\text { Kumar et al } \\
\text { (2010) }\end{array}$ & 1800 & Assessed & Mentioned & $\begin{array}{l}\text { Overall prevalence } \\
=20.1 \%\end{array}$ & Sufficient \\
\hline $\begin{array}{l}\text { 6.Nagarajan } \\
\text { S et al } \\
\text { (2010) }\end{array}$ & 1618 & $\begin{array}{l}\text { Not } \\
\text { assessed }\end{array}$ & Mentioned & $\begin{array}{l}\text { Overall prevalence } \\
=21 \%\end{array}$ & Fair \\
\hline
\end{tabular}




\begin{tabular}{|l|l|l|l|l|l|}
\hline Study & $\begin{array}{l}\text { No: of } \\
\text { subjects }\end{array}$ & $\begin{array}{l}\text { Exposure } \\
\text { variables }\end{array}$ & $\begin{array}{l}\text { Outcome } \\
\text { variables }\end{array}$ & Findings & $\begin{array}{l}\text { Relevance } \\
\text { criteria }\end{array}$ \\
\hline $\begin{array}{l}\text { 7. Singh A et } \\
\text { al (2011) }\end{array}$ & 927 & Assessed & Mentioned & $\begin{array}{l}\text { Overall prevalence } \\
=18 \%\end{array}$ & Sufficient \\
\hline $\begin{array}{l}\text { 8.Chandra } \\
\text { sekhara R et } \\
\text { al (2011) }\end{array}$ & 300 & Assessed & Mentioned & $\begin{array}{l}\text { Overall prevalence } \\
=73.7 \%\end{array}$ & Sufficient \\
\hline $\begin{array}{l}\text { 9. Oral } \\
\text { health survey } \\
\text { \& fluoride } \\
\text { mapping of } \\
\text { Bengaluru } \\
\text { (2011) }\end{array}$ & 2503 & $\begin{array}{l}\text { Not } \\
\text { assessed }\end{array}$ & Mentioned & $\begin{array}{l}\text { Prevalence among } \\
12 \text { years }=19.1 \% \\
15 \text { years }=14.9 \%\end{array}$ & Fair \\
\hline $\begin{array}{l}\text { 10. Garcha V } \\
\text { et al (2011) }\end{array}$ & 3500 & $\begin{array}{l}\text { Not } \\
\text { assessed }\end{array}$ & Mentioned & $\begin{array}{l}\text { Overall prevalence } \\
=40.5 \%\end{array}$ & Fair \\
\hline $\begin{array}{l}\text { 11.Jagan } \\
\text { Kumar et al } \\
\text { (2013) }\end{array}$ & 1800 & Assessed & Mentioned & $\begin{array}{l}\text { Overall prevalence } \\
=15.4 \%\end{array}$ & Sufficient \\
\hline
\end{tabular}

\begin{tabular}{|l|l|l|l|l|l|}
\hline Study & $\begin{array}{l}\text { No: of } \\
\text { subject } \\
\text { s }\end{array}$ & $\begin{array}{l}\text { Exposure } \\
\text { variables }\end{array}$ & $\begin{array}{l}\text { Outcome } \\
\text { variables }\end{array}$ & Findings & $\begin{array}{l}\text { Relevanc } \\
\text { e criteria }\end{array}$ \\
\hline $\begin{array}{l}\text { 12. Pruthi N } \\
\text { et al (2013) }\end{array}$ & 961 & Assessed & Mentioned & $\begin{array}{l}\text { Prevalence among } \\
12 \text { years }=55.8 \% \\
15 \text { years }=52.7 \%\end{array}$ & Sufficient \\
\hline $\begin{array}{l}\text { 13. Shailee } \\
\text { F et al } \\
\text { (2013) }\end{array}$ & 1011 & $\begin{array}{l}\text { Not } \\
\text { assessed }\end{array}$ & Mentioned & $\begin{array}{l}\text { Prevalence among } \\
12 \text { years }=58.1 \% \\
15 \text { years }=54.5 \%\end{array}$ & Fair \\
\hline $\begin{array}{l}\text { 14.Chandra } \\
\text { sekhar BR } \\
\text { et al (2013) }\end{array}$ & 1268 & $\begin{array}{l}\text { Not } \\
\text { assessed }\end{array}$ & Mentioned & $\begin{array}{l}\text { Overall prevalence }= \\
18.2 \%\end{array}$ & Fair \\
\hline $\begin{array}{l}\text { 15. } \\
\text { Chauhan d } \\
\text { et al (2014) }\end{array}$ & 1188 & Assessed & Mentioned & $\begin{array}{l}\text { Overall prevalence }= \\
12.5 \%\end{array}$ & Sufficient \\
\hline $\begin{array}{l}\text { 16. } \\
\text { Havaldar } \\
\text { KS et al } \\
\text { (2014) }\end{array}$ & 300 & $\begin{array}{l}\text { Not } \\
\text { assessed }\end{array}$ & Mentioned & $\begin{array}{l}\text { Overall prevalence= } \\
10.7 \%\end{array}$ & Fair \\
\hline $\begin{array}{l}\text { 17. Singh } \\
\text { M et al } \\
\text { (2014) }\end{array}$ & 836 & $\begin{array}{l}\text { Not } \\
\text { assessed }\end{array}$ & Mentioned & $\begin{array}{l}\text { Overall prevalence }= \\
34.1 \%\end{array}$ & Fair \\
\hline
\end{tabular}

\section{Discussion}

A systematic review on prevalence of malocclusion among Indian children aged 12-15 years using DAI index was undertaken from February 2014. Malocclusion prevalence all over India ranges from as low as $11.4 \%$ to as high as $73.7 \%$. Crowding and maxillary overjet are the most common orthodontic anomalies among Indian children. Today malocclusion occurs in the majority of the population. It is neither a normal or unhealthy condition (Proffit \& Fields, 2000) ${ }^{2}$. Malocclusion is an appreciable deviation from the ideal occlusion that may be considered aesthetically unsatisfactory (Houston, et al., 1992) ${ }^{3}$ thus inferring a condition of imbalance in the relative dimensions and location of teeth, facial bones and soft tissues (lips, cheek, and tongue). Possession of malocclusion should not be equated with the need for a treatment instead it should be umpired according to 
dental health, aesthetic or well-designed criteria namely: chewing, speech, breathing and swallowing (Sampson \& Sims, 1992) ${ }^{3}$.

Variations in malocclusion status could be due to genetic predisposition, cross cultural differences in living standards, variations in growth, facial skeleton development and occlusion. The adverse effects of malocclusion on oral health and social or psychological well-being of the individual is one of most important aspect which should receive priority before treatment considerations. Many studies have used Angle's classifications or various modifications of this system, which will lay on the line comparison of the total prevalence of malocclusion qualities. Hence it is difficult to compare their findings, because of the varying methods and indices used to assess and record occlusal relationships. Other variables including examiner subjectivity and specific objectives further complicate efforts to understand and record the differences.

Information provided by this review can be used as a preliminary data. Further large scale epidemiological studies are required to confirm these findings. The significance of the association between oral habits and malocclusion as a causative factor should be interpreted cautiously as this review did not take in to consideration the effect of oral habits along with genetic and environmental factors. ${ }^{9}$

This review suggests that there is need for intensified oral health education in India targeted at both parents and school children to enable them to use the interceptive orthodontic care which has numerous effects. With relatively economical removable appliances, such as expansion appliances, habit-breaking appliances, space maintainers and crossbite correction appliances, interceptive orthodontics can be easily consummated. It is recommended that preventive and interceptive services are incorporated starting at an early age to target the primary dentition and then in mixed dentition. This is basic for the formulation of oral health policies and implementation of appropriate programmes to improve the awareness and knowledge of people on the preventive aspects of oral health, create needed services and train the dental manpower to meet those needs.

\section{Bibliography}

[1]. Bali RK, Mathur VB, Talwar PP, Chanana HB. National Oral Health Survey and Fluoride Mapping 2002-2003, India.

[2]. Sureshbabu AM, Chandu GM, Shafiulla MD. Prevalence of malocclusion and orthodontic treatment needs among 13-15 year old school going children of Davangere city, Karnataka, India. J Indian Assoc Public Health Dent 2005; 6: 32-5.

[3]. Shivakumar KM, Chandu GN, Subba Reddy VV, Shafiulla MD. Prevalence of malocclusion and orthodontic treatment needs among middle and high school children of Davangere city, India by using Dental Aesthetic Index. J Indian Soc Pedod Prev Dent 2009; $27: 211-8$.

[4]. Pankaj S. Prevalence of malocclusion and orthodontic treatment needs among 12-15 years school children using DAI. J Indian Assoc Public Health Dent 2010; 15: 81-4.

[5]. Shivakumar KM, Chandu GN, Shafiulla MD. Severity of malocclusion and orthodontic treatment needs among 12-15 year old school children of Davangere District, Karnataka. Eur J Dent 2010; 4: 298-307.

[6]. Sripriya Nagarajan, Krishnappa P. The relationship of malocclusion assessed by DAI with perception of aesthetics, Function, Speech and treatment needs among 14-15 year old school children of Bangalore, India. Oral Health Prev Dent 2010; 8: 221-8.

[7]. A. Singh, B. Purohit, P. Sequeria. Malocclusion and orthodontic treatment need measured by DAI and its association with dental caries in school children. Community Dental Health 2011; 28: 311-16.

[8]. Chandrasekhara R, Hema Priya. Prevalence of malocclusion and orthodontic treatment needs among 12-15 years old school children of Chennai. J Indian Assoc Public Health Dent 2011; 18(1): 591-97.

[9]. Oral health survey \& fluoride mapping of Bengaluru district 2011. Indian Association of Public Health Dentistry, Bengaluru chapter.

[10]. Vikram G, Sahana H, Pradanya H. Oral health assessment and treatment needs of the students in Maharashtra. J Indian Assoc Public Health Dent 2011; 17(1): 249-54.

[11]. Jagan KB, Amrita G, Clement R, Anil T. Prevalence of malocclusion and its relationship with caries among school children aged 11-15 years in southern India. Korean J Orthod 2013; 43(1):35-41.

[12]. Nidhi P, Girish M, Shailee F. Malocclusion and deleterious oral habits in a North Indian adolescent population: A correlational study. Eur J Gen Dent 2013; 2: 257-63.

[13]. Shailee F, Girish S, Sharma K, Pruthi Nidhi. Oral health status and treatment needs among 12-15 year old government and private school children in Shimla, Himachal Pradesh, India. J Int Soc Prev Community Dent 2013 Jan-Jun; 3(1): 44-50.

[14]. Chandra Shekar BR, Suma S, Sudarshan K, Jagadeeshwara R, Manjunath. Malocclusion status among 15 years old adolescents in relation to fluoride concentration and area of residence. Ind J Dent Research 2013; 24(1): 35-41.

[15]. Deepak C, Vinod S, Tripti C, Kamal KG. A study on malocclusion and orthodontic treatment needs according to DAI among school children of a hilly state of India. J Indian Soc Prev Commun Dent 2013 Jan-Jun 2013; 3(1): 32-6.

[16]. Havaldar KS, Bhat SS, Hegde SK. Oral health status of Tibetan and local school children of Mysore, India: A comparative study. J Indian Soc Pedod Prev Dent 2014 Apr- Jun; 32(2): 125-129.

[17]. Meghna Singh, Ashish S, Charanjeet S, Anoop B. Prevalence of dental diseases in 5-14 year old school children in rural areas of Barabanki, Uttar Pradesh, India. Ind J Dent Research 2011;22(3):396-9.

[18]. Bhardwaj VK, Veeresha KL, Sharma KR. Prevalence of malocclusion and orthodontic treatment needs among 16-17 year old school going children in Shimla city, Himachal Pradesh. Indian J Dent Res 2011; 22: 556-60.

[19]. Anita G, Anil Kumar G, Vamsi R, Praveen Kumar Reddy, Rama Rao MS, Swapnil BW. Dental Aesthetic Index of school students in Telangana region- An epidemiological study. J Int Oral health Nov- Dec 2013; 5(6):55-60.

[20]. Vishnu PS, Shiv Kumar M, Madan KP, Suresh Babu AM. Oral health status and treatment needs of a residential school children aged 3-15 years in Chennai city. JIAPHD 2011; 17(1): 309-13.

[21]. Dinesh Rao B, Arnitha HM, Munshi AK. Malocclusion and orthodontic treatment need of handicapped individuals in South Canara, India. Int Dental Journal 2003; 53: 13-8.

[22]. Mahesh Kumar P, Joseph T, Varma RB, Jayanth M. Oral health status of 5year and 12 year school going children in Chennai city: an epidemiological study. J Ind Soc Pedo Prev Dent 2005; 23: 17-22. 
[23]. Jose A, Joseph MR. Prevalence of dental health problems among school going children in rural Kerala. J Ind Soc Pedo Prev Dent Dec 2003; 21(4): 147-51.

[24]. Joseph J, Dhinahar S, Reddy PS. Prevalence of malocclusion and treatment needs of 12 year old school children of Chennai using DAI 2011; 25: 14-21.

[25]. Dhar V, Jain A, Van Dyke TE, Kohli A. Prevalence of gingival diseases, malocclusion and fluorosis in school going children of rural areas in Udaipur district. J Ind Soc Pedo Prev Dent Jun 2007; 2: 103-5.

[26]. Das UM, Beena JP, Aher U. Oral health status of 6 and 12 year old school children in Bangalore city: An epidemiological study. J Ind Soc Pedo Prev Dent Jan- Mar 2009; 27(1): 6-8.

[27]. Kaur H, Pavithra US, Abraham R. Prevalence of malocclusion among adolescents in South Indian population. J Int Soc Prev Community Dent July 2013; 3(2): 97-10.

[28]. de Lugt - Lustig, Vanobbergen, Vander Putten, De Visschere, Schols , de Baat C. Effect of oral healthcare education on knowledge, attitude and skills of care home nurses- a systematic review. Community Dent Oral Epidemiol 2014; 42: 88-96. 